\title{
Latent Entrepreneurship Across Nations
}

Forthcoming in the European Economic Review

\author{
David G Blanchflower \\ Department of Economics \\ Dartmouth College \\ USA \\ blanchflower@dartmouth.edu
}

\author{
Andrew Oswald \\ Department of Economics \\ Warwick University \\ UK \\ andrew.oswald@warwick.ac.uk
}

Alois Stutzer

University of Zurich

Switzerland

astutzer@iew.unizh.ch

Revised January 22, 2001

For their helpful ideas, we thank the editor and Marc Cowling, Chris Pissarides and David Storey. 


\begin{abstract}
The paper studies latent entrepreneurship across nations. There are three main findings. First, large numbers of people in the industrial countries say they would prefer to be self-employed. Top of the international ranking of entrepreneurial spirit come Poland (with $80 \%$ saying so), Portugal and the USA; bottom of the table come Norway (with 27\% saying so), Denmark and Russia. Second, for individuals the probability of preferring to be self-employed is strongly decreasing in age, while the probability of being self-employed is strongly increasing in age. Third, we show that self-employed individuals have noticeably higher job satisfaction than the employed, so people's expressed wish to run their business cannot easily be written off as mistaken. We speculate on why so much entrepreneurial spirit lies dormant.
\end{abstract}




\title{
Latent Entrepreneurship Across Nations
}

\author{
David G Blanchflower, Andrew Oswald and Alois Stutzer
}

\section{Introduction}

It is sometimes argued that nations differ in their underlying entrepreneurial spirit. The United States, in particular, is often singled out as a country with an inherently large number of people who are keen to start firms. Europe, it is sometimes asserted, lacks entrepreneurial individuals. While some politicians argue that Eastern Europe is in particular need of people who wish to run their own businesses, there is especially little information about the potential supply of entrepreneurs in that region of the world.

Few economists have attempted to measure entrepreneurial spirit across countries. We use newly available data to create an international league table of what might be thought of as the simplest measure of entrepreneurial drive. There are obvious difficulties in attempting to measure something so subtle, but the topic appears important.

We focus in the paper on self-employment. This is the simplest form of entrepreneurial activity. Such people have made a job for themselves, and often for others. Medium-size companies tend to have grown from a small business organized by a self-employed man or woman. Selfemployment also has the advantage that it can be defined fairly consistently across countries. Although there are people inside giant corporations who may be entrepreneurial on certain definitions, it is not easy to know how to identify them.

The paper is also interested in microeconomic patterns. It examines the micro-econometric structure of both the preference for, and the attainment of, self-employment across nations. Hence two kinds of probit equations are estimated using data on individuals. One is for being self-employed; the other is for answering yes to a question asking people whether they would prefer to be self-employed. There are strong differences in the age structure of the two equations. 
Some measure of potential or latent entrepreneurship is needed. The paper measures entrepreneurial spirit by using the question:

"Suppose you were working and could choose between different kinds of jobs. Which would you prefer:

being an employee

being self-employed?"

It is possible to think of many objections to this wording (from an economist's point of view it is vague on the constraints under which people are assumed to make their hypothetical choice), but it has the merit of simplicity. Moreover, because the wording is chosen deliberately to be consistent across countries, and our concern is to produce international comparisons, some of the question's drawbacks are reduced. If there are biases in the question's wording, those biases may be similar across nations and thus still give useful cross-country information.

The question is asked in a newly released International Social Survey Programme data set. Information on more than twenty countries is available.

Individuals in ISSP are chosen randomly. They were interviewed face-to-face in a period spanning 1997 and 1998.

For the analysis reported here, the sample size is approximately 25,000 individuals across 23 nations. Blanchflower (2000) and OECD (2000) look at related international self-employment statistics for OECD countries. But information on self-employment preferences in the 1990s has until now been sparse.

\section{Means}

Table 1 contains the mean responses by country. 
To fix preliminary ideas, it is clear that an economist would not expect a large proportion of people to answer in favour of self-employment. The vast majority of workers (almost nine out of ten, in most nations) in the industrial countries are conventional employees: they draw a pay check from a firm that someone else began. There is one small exception. In heavily agricultural sectors, and nations, the numbers of self-employed individuals tend to be higher; but the western democracies now have only tiny percentages of their population in agriculture. Moreover, the western nations have sophisticated banking systems, stock markets, and networks of venture capitalists. On the face of it, there are many opportunities to borrow to back a good idea for a business start-up. At the turn of the $21^{\text {st }}$ century, therefore, an economist would not expect many of those who covet a chance to be self-employed to be thwarted in that wish.

However, the patterns in the answers are not what would have been predicted. There are apparently huge numbers of frustrated entrepreneurs.

First, the survey data of Table 1 reveal a strikingly large latent desire to be in charge of one's own business. Even in countries at the bottom of the table, a quarter of the population say they would prefer to be self-employed. This compares to an actual proportion of self-employed people in most countries of around $10 \%-15 \%$ of the labour force (see the figures in the first column of Table 1). It is interesting to wonder why so few individuals manage to translate their preferences into action. Lack of start-up capital may be one explanation, and we return to that possibility later.

Objections are certainly possible. These subjects are asked a hypothetical question, in an unrealistic setting, and their answers may therefore be unrepresentative of the truth in a practical or implementable sense. The harshest of critics might argue that one could imagine a question 'if you were working and could choose between different kinds of jobs, would you prefer to be in your current job or be a top tennis player?', and that the answers to this might also be highly positive and yet not tell us very much except that people would like to earn as much as Pete Sampras. 
There is probably something to this criticism. Nevertheless, our aim is to capture the inherent level of entrepreneurial interest, not merely the level that is currently converted into activity. It would be extreme to view these survey answers as containing no useful food for thought. Moreover, while winning Wimbledon is beyond the scope of almost anyone, it is not clear that the same can be said of being self-employed. Almost all people could be self-employed if they wished (perhaps on a low income); that is not true of the tennis question. And as the same question is asked everywhere, the relative responses should be meaningful.

The most compelling case, however, emerges from the structure of the answers. The numbers in Table 1 are so large, and information in the area sufficiently sparse, that we think it unwise to disregard answers of this type. In the late 1990s, in these countries, the data suggest that there is considerable interest in the idea of being self-employed.

Second, and intriguingly, there is marked variation by nation. The proportions of people who favour self-employment vary from $80 \%$ to less than $30 \%$.

Poland, Portugal and the USA top the league table. It appears that approximately three-quarters of these nations' citizens would like to manage their own business rather than work for a company as a regular employee. These proportions seem extraordinarily large, but we simply report them. Bottom of the league table of latent entrepreneurship come Russia, Denmark and Norway. In these nations, roughly $30 \%$ of citizens say they are interested in being self-employed. Two developing countries are in the data set but, because of their reliance on agriculture, we choose not to include the numbers. They are Bangladesh and the Philippines. The island of Cyprus is also in the data. Although it is now close to an officially advanced western country, we decided on balance to omit it. For the record, self-employment and expressed desire for it are both high in all three of these countries, but we are not confident that it is possible to make valid comparisons with the more heavily industrial nations in the rest of the sample.

Emerging industrial nations are interesting. The idea that Eastern Europe lacks potential entrepreneurs -- when compared to the advanced nations -- appears to be wrong. Not only, 
according to our data, is Poland the country with the single highest expressed level of interest in self-employment, but Eastern Europe is represented evenly throughout the ranking.

It is interesting that Portugal, the US and Switzerland are so high in the table. They are famously among the low-unemployment countries of the world. Politicians routinely assert that the supply of entrepreneurial individuals should be fostered because that raises prosperity and creates jobs. Disentangling cause and effect, however, is not possible in a simple analysis. Moreover, Netherlands, for example, is near the bottom of Table 1 and yet has small levels of joblessness. Japan is unexpectedly low, in the international ranking of desire for self-employment, at number 16 in our league table of entrepreneurial spirit. Britain ranks 14 out of the 23 nations.

For those who believe that the industrialized nations need more entrepreneurs, the message of the paper may be viewed as encouraging. People in these sorts of countries have strong underlying interest in (one form of) entrepreneurial behaviour.

\section{Micro-econometric Patterns}

It is natural to look a little more closely at the data. To set the scene, Table 2 presents the simplest kind of self-employment probit equation. We report estimated derivatives from these models that can be interpreted as the effect on the probability of being self-employed of an infinitesimal change in each independent continuous variable and the discrete change in the probability for dummy variables. Table 2 takes as its sample all those in work (of any kind) in the ISSP data for 1997. Here the dependent variable is set to one if the person reports themselves as self-employed and set to zero otherwise. The sample size is approximately 16,000 people.

Country dummy variables are included in Table 2. The omitted base category is West Germany. The dummies provide a snapshot view of the international pattern of self-employment. Italy is near the top of the ranking, for instance, while East Germany is near the bottom.

The probability of being self-employed is lower among highly educated workers. The t-statistic on years of schooling is well-determined at 8.99 in the first column of Table 2. Compositional 
variables on full-time/part-time matter. As is known, a variable for being male enters strongly positively in a self-employment equation. Age also enters positively, with a small standard error.

Table 3 contains information that would have been less easily anticipated. It estimates for men and women, from a sample of employees, the probability of an individual saying they would prefer to be self-employed rather than work for somebody else.

First, age now enters Table 3's probit equation strongly negatively. In other words it has the opposite sign from that for age in the being-self-employed equation of Table 2. This means that, despite the fact that older people are more likely to be self-employed, it is younger people who say they would prefer to be self-employed.

A potential explanation is a kind of dynamic one. As they age, people simply flow into selfemployment. Hence those who say when young that this is their aim gradually achieve that aim. But this cannot account for the much larger numbers asserting that self-employment is desirable relative to the small numbers who end up as self-employed.

Second, the structure of the country dummies is not identical to that for actual self-employment in the previous table. As in the raw cross-tabulations of Table 1, Denmark and Norway are low in the implied dummy-variable ranking of Table 3. Poland and Portugal are again high.

The notable feature is the contrast between age in Table 2 and in Table 3. Huge numbers of young workers in these industrial countries would prefer self-employment (or at least claim that they would). We know this from the fact that for the young the average numbers in Table 1 are an understatement -- as they are for the full sample and the age coefficient in the regression is negative -- of the amount of desire to be entrepreneurial.

Our results cannot be definitive because they rely on what people say they want. Yet they seem suggestive - leaving it natural to think that in these nations there may be a currently unexploited supply of entrepreneurial individuals. 
Young people are apparently particularly constrained to be workers rather than run their own businesses. If age entered with a zero coefficient in Table 3, we could conclude that entrepreneurship choice was unconstrained by a person's age. A zero would signify that older workers preferred self-employment neither more nor less than the young. But that is not what the data show. As a person becomes older it becomes easier to break into entrepreneurship.

\section{Are People Simply Mistaken to Prefer the Idea of Self-Employment?}

A traditional economist might reason in the following way. One possible explanation for the high numbers in Table 1 is that people are simply mistaken. Perhaps they have an unrealistically rosy view of what it is like to be running one's own business rather than have the comparative security of being an employee. One reason economists are often wary of subjective data is because people are sometimes thought to be unable to judge what will be in their own interest.

But Table 4 provides counter evidence. It shows, using a recent sweep of the Eurobarometer Surveys, that feelings of job satisfaction are higher among the self-employed. This is a rather robust finding across the nations on which data are available. It is not merely a result found in cross-tabulations of the type in Table 4. We have checked that job-satisfaction regression equations (not reported) confirm that a dummy for self-employment enters strongly positively.

\section{One Possible Interpretation}

Why, then, are there so many frustrated entrepreneurs (especially among the young) in economies of this sort?

It is not easy to know what lies behind the paper's numbers, but recent research leads us to one possibility. Economists have amassed considerable evidence that potential entrepreneurs are held back by lack of capital. 
Blanchflower and Oswald, 1998, for example, look at three kinds of evidence. First, the receipt of an inheritance or gift seems to increase a typical individual's probability of being selfemployed. This emerges from British data drawn from the National Child Development Survey. NCDS traces from birth a cohort of children born in 1958. These individuals have been followed for the whole of their lives. Blanchflower and Oswald find a large association between selfemployment and receiving money early on. The inheritance effect is found at age 23 and 33 . It is especially large in the former and younger group. Second, Blanchflower and Oswald (1998) report British Social Attitudes Survey data. Although this tells us only about one country, the survey responses were intriguing. Interviewing a sample of those who did not become selfemployed but who considered it, the main explanation given by people to the survey team was that they could not raise the start-up capital. Third, consistent with the tenor of these, Blanchflower and Oswald use data from the UK National Survey of the Self-Employed to conclude that

(i) most small businesses are begun with own or family money,

(ii) individual entrepreneurs said they had needed most help with finance, and

(iii) at the start the single biggest concern of potential entrepreneurs was with where to obtain capital.

Earlier work by Evans and Jovanovic (1989) and Holtz-Eakin, Joulfaian and Rosen (1994) drew similar conclusions using different methods on US data. They did not have direct evidence of capital constraints, but instead showed that large amounts of assets help in regressione equations to predict transitions into self-employment. In a similar spirit, the work of Black et al (1996) for the UK discovers an apparently powerful role for housing prices (through its impact on equity 
withdrawal - meaning that those who have made capital gains by owning houses may use the capital to start their own firms) in affecting the supply of small new firms. Again this is suggestive of capital constraints. Finally, Lindh and Ohlsson (1994) adopt the BlanchflowerOswald procedure to look for a natural experiment in which some people receive windfalls. They focus on lottery winnings, and, by showing that winners were afterwards more likely to set up in business, provide complementary evidence for Sweden.

It is worth emphasizing that this kind empirical work does not prove governments should be handing out capital to those who wish to go into business. The paper's findings are positive rather than normative. Nevertheless, it suggests that if there is much latent entrepreneurship (and the earlier sections of the paper imply that that is plausible), then one way to increase the numbers putting their preferences into practice would be somehow to make it easier for such people to raise capital. The numbers in tables like Table 1 are sufficiently high to make one doubt the view that the market is working completely efficiently here.

\section{Conclusions}

This paper is an attempt to study entrepreneurial spirit across nations. Its approach is a simple one. The paper uses the answers to a survey question about people's desire to be self-employed. Using random samples of individuals, large differences are found across 23 countries. Poland tops the international ranking of latent entrepreneurial spirit. Norway is lowest.

The paper also estimates separate probit equations for being self-employed and preferring to be self-employed. They reveal interesting differences. In particular, age enters positively in the first equation and negatively in the second. We show, too, that self-employed people have noticeably greater job satisfaction than the employed, so Table 1's large expressed desire to be selfemployed cannot easily be written off as individuals making mistakes. 
The latent supply of entrepreneurs appears to be much larger than is commonly supposed. Our hunch - it cannot be more than that at this juncture - is that lack of capital currently holds back millions of potentially entrepreneurial people in the industrial countries. 


\section{Table 1.}

\section{Latent Entrepreneurship: An International League Table}

Survey question: Suppose you were working and could choose between different kinds of jobs. Which would you prefer:

being an employee

being self-employed?

\section{Self-employment \% \% people who say they would prefer to be self-employed}

$\mathrm{N}$

$\begin{array}{lccl}\text { Poland } & 30.2 & 79.9 & 922 \\ \text { Portugal } & 26.2(28.7) & 73.3 & 1616 \\ \text { USA } & 14.0(8.4) & 70.8 & 1071 \\ \text { Switzerland } & 13.6 & 64.5 & 2216 \\ \text { New Zealand } & 22.7(20.4) & 64.2 & 1046 \\ \text { West Germany } & 10.1 & 64.0 & 957 \\ \text { Italy } & 30.4(28.9) & 63.3 & 973 \\ \text { Slovenia } & 9.8 & 57.8 & 820 \\ \text { Canada } & 16.6(11.3) & 57.5 & 857 \\ \text { East Germany } & 6.1 & 56.6 & 389 \\ \text { Bulgaria } & 13.2 & 55.4 & 900 \\ \text { Hungary } & 13.9 & 49.8 & 1419 \\ \text { Israel } & 22.1 & 49.7 & 972 \\ \text { Great Britain } & 15.6(13.6) & 45.1 & 953 \\ \text { France } & 9.1(11.6) & 41.8 & 918 \\ \text { Japan } & 28.7(17.7) & 40.9 & 1065 \\ \text { Spain } & n / a(25.0) & 38.9 & 1138 \\ \text { Sweden } & 11.1(11.0) & 38.8 & 1129 \\ \text { Czech Republic } & 10.7 & 36.8 & 961 \\ \text { Netherlands } & n / a & 36.0 & 2013 \\ \text { Russia } & 8.5 & 33.2 & 1409 \\ \text { Denmark } & 6.7(9.5) & 29.7 & 992 \\ \text { Norway } & 9.9(8.7) & 26.9 & 2021 \\ & & & \end{array}$

$\mathrm{N}$ is the number of people interviewed in each nation. A sample of the whole adult population is interviewed. The Israel sample is for Israeli Jews only. Data for Cyprus, Bangladesh and Philippines are omitted.

Numbers in the first column are for comparison. They give actual self-employment rates for OECD countries from, respectively, OECD Labour Force Statistics and, in parentheses where data are available, Blanchflower (2000).

Source: 1997/8 ISSP Module on Work Orientations / General Social Survey. 


\section{Table 2. Probability of Being Self-Employed (Probit Equation)}

\begin{tabular}{|c|c|c|c|}
\hline & $A l l$ & Male & Female \\
\hline Age & .004 (14.66) & $.004(11.66)$ & $.003(9.02)$ \\
\hline Male & $.07(11.65)$ & $\mathrm{n} / \mathrm{a}$ & $\mathrm{n} / \mathrm{a}$ \\
\hline Part-time main job & $.03(3.19)$ & $.08(4.25)$ & $.01(0.83)$ \\
\hline Less than part-time & $.01(0.82)$ & $.01(0.21)$ & $.02(0.82)$ \\
\hline Years schooling & $-.01(8.99)$ & $-.01(7.71)$ & $-.01(4.71)$ \\
\hline Bulgaria & $.05(1.86)$ & $.08(2.08)$ & $.01(0.29)$ \\
\hline Canada & $.13(4.66)$ & $.14(3.36)$ & $.12(3.12)$ \\
\hline Czech Republic & $.03(1.14)$ & $.03(0.89)$ & $.02(0.68)$ \\
\hline Denmark & $-.05(2.14)$ & $-.04(1.25)$ & $-.05(1.81$ \\
\hline East Germany & $-.06(1.83)$ & $-.10(2.13)$ & $-.01(0.31)$ \\
\hline France & $-.06(2.41)$ & $-.05(1.52)$ & $-.05(1.89$ \\
\hline Great Britain & $.08(2.95)$ & $.14(3.64)$ & $.02(0.49)$ \\
\hline Hungary & $.08(3.08)$ & $.09(2.47)$ & $.06(1.77)$ \\
\hline Israel - Arabs & $.22(5.59)$ & $.29(5.84)$ & $-.05(0.81)$ \\
\hline Israel - Jews & $.16(5.54)$ & $.22(5.55)$ & $.06(1.70)$ \\
\hline Italy & $.26(8.93)$ & $.25(6.27)$ & $.30(6.51)$ \\
\hline Japan & $.21(7.65)$ & $.19(5.21)$ & $.22(5.53)$ \\
\hline New Zealand & $.17(5.14)$ & $.14(3.03)$ & $.19(4.16)$ \\
\hline Norway & $.01(0.42)$ & $.03(0.90)$ & $-.01(0.37)$ \\
\hline Poland & $.26(9.16)$ & $.30(7.49)$ & $.20(5.12)$ \\
\hline Portugal & $.15(5.84)$ & $.17(4.79)$ & $.11(3.29)$ \\
\hline Russia & $.01(0.29)$ & $.02(0.56)$ & $-.01(0.39)$ \\
\hline Slovenia & $.03(0.98)$ & $.04(0.92)$ & $.01(0.37)$ \\
\hline Sweden & $-.003(0.14)$ & $.03(0.80)$ & $-.03(1.15)$ \\
\hline Switzerland & $.04(1.79)$ & $.03(0.93)$ & $.05(1.70)$ \\
\hline USA & $.08(3.38)$ & $.10(2.73)$ & $.06(1.94)$ \\
\hline $\mathrm{N}$ & 16485 & 9145 & 7336 \\
\hline $\mathrm{Chi}^{2}$ & 2001.15 & 1068.48 & 764.93 \\
\hline Log likelihood & -6935.7 & -4386.11 & -2501.68 \\
\hline Pseudo $\mathrm{R}^{2}$ & 0.1261 & 0.1086 & 0.1326 \\
\hline
\end{tabular}

Source: International Social Survey Programme, 1997/8. Dummies were included, but are not reported, for Bangladesh, Philippines and Cyprus. Excluded category West Germany.

Notes: The dependent variable is 1 if self-employed and zero if employed. T-statistics are in parentheses. Sample consists of workers only. Estimation procedure is dprobit in STATA. 


\section{Table 3. Probability of Preferring to be Self-Employed (Probit Equation)}

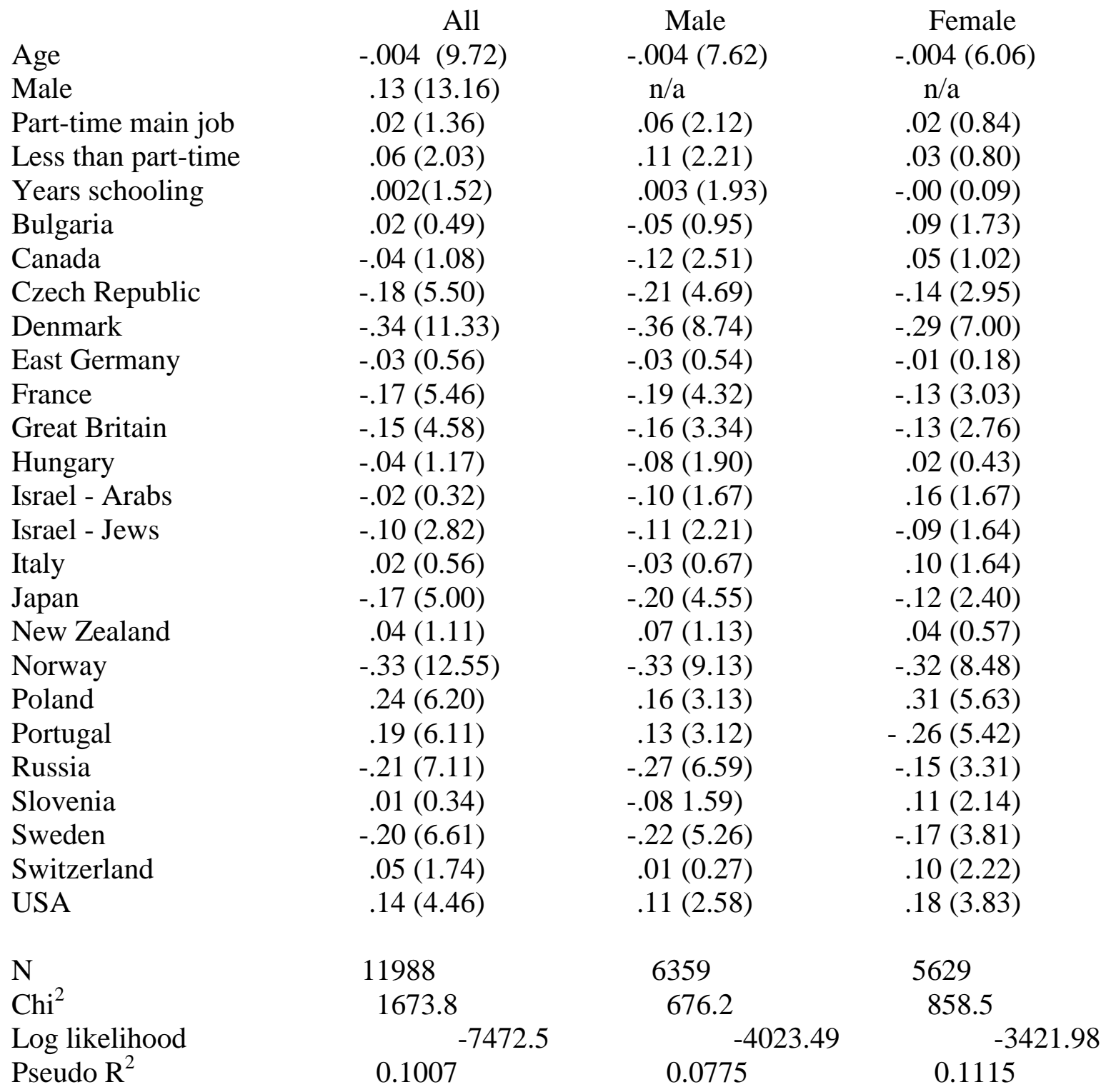

Source: International Social Survey Programme, 1997. Dummies were included but are not reported for Bangladesh, Philippines and Cyprus. Excluded category West Germany.

Notes: The dependent variable is 1 if wants to be self-employed and zero if would prefer to be an employee. T-statistics are in parentheses. Sample consists of employees only. 
Table 4. Job Satisfaction of the Employed and Self-Employed (\%).

a) Employees

$\begin{array}{ll}\text { Belgium } & 1 \\ \text { Denmark } & 2 \\ \text { West Germany } & 5 \\ \text { Greece } & 6 \\ \text { Italy } & 5 \\ \text { Spain } & 4 \\ \text { France } & 5 \\ \text { Ireland } & 1 \\ \text { Luxembourg } & 2 \\ \text { Netherlands } & 1 \\ \text { Portugal } & 3 \\ \text { Great Britain } & 5 \\ \text { East Germany } & 2 \\ \text { Finland } & 2 \\ \text { Sweden } & 2 \\ \text { Austria } & 1 \\ \text { Euro 15 } & 4\end{array}$

b) Self-employed

Belgium 0

Denmark 0

West Germany 2

Greece 13

Italy

Spain

France

Ireland

Luxembourg

Netherlands

Portugal

Great Britain

East Germany

Finland

Sweden

Austria

Euro 15

$\begin{aligned} & \text { Not at all } \\ & \text { Not very } \\ & \text { satisfied }\end{aligned}$
satisfied

$\begin{array}{ll}1 & \\ 2 & \\ 5 & \\ 6 & \\ 5 & 25 \\ 4 & 1 \\ 5 & 1 \\ 1 & 1 \\ 2 & \\ 1 & \\ 3 & \\ 5 & \\ 2 & \\ 2 & \\ 2 & \\ 1 & \\ 4 & \end{array}$

\author{
Fairly \\ satisfied
}

Very
satisfied

52

45

52

56

57

57

61

39

56

47

62

49

57

63

55

47

54
41

49

32

13

20

23

20

55

35

44

21

37

33

31

37

43

30

54

61

49

10

39

26

28

67

62

59

23

46

41

32

63

52

38
775

919

889

526

727

757

862

775

418

962

696

925

927

903

967

937

12965

233

73

135

476

301

239

126

229

71

101

299

137

119

150

88

128

2905

Notes: sample consists of those in work. All estimates are weighted. Source is Eurobarometer \#44.2: Working conditions in the European Union, November 1995-January 1996. 


\section{$\underline{\text { References }}$}

Black, J., De Meza, D. and Jeffreys, D., 'House Prices, the Supply of Collateral, and the Enterprise Economy', Economic Journal, 106, January 1996, 60-75.

Blanchflower, D.G., 'Self-Employment in OECD Countries', Labour Economics, 7, September 2000, 471-505.

Blanchflower, D.G. and Oswald, A.J., 'What Makes an Entrepreneur?', Journal of Labor Economics, 16, January 1998, 26-60.

Evans, D. and Jovanovic, B., 'An Estimated Model of Entrepreneurial Choice under Liquidity Constraints', Journal of Political Economy, 97, 1989, 808-927.

Holtz-Eakin, D., Joulfaian, D., and Rosen, H.S., 'Entrepreneurial Decisions and Liquidity Constraints', Rand Journal of Economics, 25 (Summer), 1994, 334-347.

Lindh, T. and Ohlsson, H., 'Self-Employment and Self-Financing', Economic Journal, 106, November 1994, 1515-26.

OECD, Employment Outlook, Organisation for Economic Cooperation and Development, Paris, 2000 . 